\title{
Evaluation of anxiolytic activity of the essential oil of the aerial part of Foeniculum vulgare Miller in mice
}

\author{
Miraf Mesfin ${ }^{1}$, Kaleab Asres ${ }^{2}$ and Workineh Shibeshi ${ }^{*}$
}

\begin{abstract}
Background: Foeniculum vulgare locally known as ensilal, is an aromatic plant widely cultivated in temperate and tropical regions. The anti-anxiety activity of the crude extract of F. vulgare has been reported. However, the fraction responsible for anxiolytic activity is not known and there is no any report on the anti-anxiety activity of the essential oil of F. vulgare. The objective of study was to evaluate the anxiolytic activity of the essential oil of Foeniculum vulgare Miller.

Methods: Adult Swiss albino male mice were randomly divided into six groups $(n=6)$. Groups I and II received Tween $80(5 \%, v / v)$ and diazepam $(0.5 \mathrm{mg} / \mathrm{kg}$, ip), respectively, while groups III to $V$ received orally 50, 100, and 200 and $400 \mathrm{mg} / \mathrm{kg}$ doses of the essential oil of $F$. vulgare, respectively. The mice were then individually placed in animal anxiety models: elevated plus maze (EPM), staircase test (SCT) and open field test (OFT) and evaluated for various parameters.
\end{abstract}

Results: In EPM test, 100 and 200 mg/kg doses of the essential oil significantly increased percent number of entries and time spent in open arms compared to control. In SCT these doses also reduced rearing significantly compared to controls, while only the $200 \mathrm{mg} / \mathrm{kg}$ dose significantly increased number of squares crossed at the center in the OFT test.

Conclusion: The essential oil of F. vulgare was found to exhibit a promising anxiolytic activity.

Keywords: Anxiolytic activity, Foeniculum vulgare, Essential oil, Mice

\section{Background}

Anxiety disorders are among the most common mental, emotional, and behavioral problems affecting one-eighth of the total population worldwide, and have become a very important area of research interest in psychopharmacology. Anxiety represents a heterogenous group of disorders, probably with no single unifying etiology; various psychodynamic, psychoanalytic, behavioral, cognitive, genetic and biological theories have been proposed to explain the etiology of anxiety disorders [1]. It is reported to have increasing prevalence in recent cohorts in many countries and to have much earlier ages of onset than other commonly occurring chronic conditions [2]. Anxiety disorders cause performance impairments on numerous tasks and are associated with high rates of medically

\footnotetext{
* Correspondence: workineh.shibeshi@aau.edu.et

${ }^{1}$ Department of Pharmacology and clinical Pharmacy, School of Pharmacy, Addis Ababa University, Addis Ababa, Ethiopia

Full list of author information is available at the end of the article
}

unexplained symptoms, increased utilization of healthcare, strongly and independently associated with chronic medical illnesses, low levels of quality of life and disability $[3,4]$. Pharmacologic treatment of anxiety through the ages has included different drugs. The first class of drugs developed (barbiturates) was highly effective, unfortunately, the barbiturates can cause respiratory arrest and have a narrow therapeutic index [5]. The benzodiazepines were developed as a safer alternative to barbiturates, however, their beneficial effects are overshadowed by the emergence of physical and psychological dependence and withdrawal reactions $[6,7]$. Other drugs used for treatment of anxiety having unfavorable side-effect profiles include buspirone $[8,9]$, antidepressants [10-12] and beta-blockers [5].

Due to adverse effects associated with the currently available drugs, patients on anxiolytic drugs usually terminate the treatment before full recovery [13]. In addition, one-third of patients in controlled studies are 
unresponsive to any one of the medications [14]. Thus, there is a critical need for development of newer anxiolytic agents. In the search for new therapeutic products for the treatment of neurological disorders, medicinal plant research, worldwide, has progressed constantly, demonstrating the pharmacological effectiveness of different plant species in a variety of animal models [15]. Several essential oils obtained from plants are employed in order to balance emotions, improve physical and mental wellbeing [16]. Foeniculum vulgare Mill. locally known as ensilal or commonly known as fennel, is an aromatic plant widely cultivated in temperate and tropical regions [17].

The chemical constituents of $F$. vulgare include essential oil, fatty acid, phenylpropanoids, monoter-penids, sesquiterpenes and coumarins. It also contains triterpenoids, tannins, flavonoids, cardiac glycosides, saponins, and other types of compounds $[18,19]$.

The essential oil of $F$. vulgare is characterized by the presence of several components including major components trans-anethole, fenchone, methyl chavicol, eugnol, limonene, $p$-anisaldehyde, $\alpha$-phellandrene, $\alpha$-pinene, 1,8cineole, $\gamma$-terpinene and $P$-cymene. Compounds such as 3 -methylbutanol, linalool, $\beta$-pinene, mycerene, $\delta$-3-carene, camphor, $\alpha$-terpinol, cis-anethole, thymol are also found in lower concentration [20]. The essential oil of $F$. vulgare is generally recognized safe as the toxicity it may cause is negligible [21].

In traditional medicine, $F$. vulgare is used to: encourage menstruation and lactation, stimulate gastrointestinal motility, relieve intestinal gas accumulation, improve eyesight, alleviate productive coughs, ease spasm, promote courage and mental strength, reduce stress and nervousness and produce calming [22,23]. The medicinal properties of $F$. vulgare as evidenced by different animal and clinical studies include, antibacterial and antifungal [24], antioxidant [25], anti-inflammatory [26], anti-atherosclerotic [27], gastroprotective [28], hepatoprotective [29], and diuretic [30]. The anti-anxiety activity of the crude extract of F. vulgare has been reported [31,32]. However, the fraction responsible for anxiolytic activity is not known and there is no any report on the anti-anxiety activity of the essential oil of $F$. vulgare.

Thus, the objective of this study was to evaluate the anxiolytic activities of essential oil of $F$. vulgare in animal models of anxiety.

\section{Methods}

Chemicals

The chemicals used in the experiment include diazepam (Intlas Pharmaceuticals, India), tween 80 (Research-lab fine Chem Industries, India), anhydrous sodium sulfate (Bio-lab laboratories Ltd, Israel) and ethyl alcohol (Changshu Yangyuan Chemical, China).

\section{Plant material}

The fresh aerial parts of $F$. vulgare were purchased from local market in Addis Ababa. The plant was identified at the National Herbarium, College of Natural Sciences, Addis Ababa University, where a voucher specimen was deposited (collection number MM001).

\section{Experimental animals}

Adult Swiss albino male mice weighting 25-35 g were obtained from rodent breeding unit of the School of Pharmacy, Addis Ababa University. The animals were housed under standard environmental conditions and were allowed free access to tap water and standard laboratory pellet ad libitum. The ethical handling (33) of mice used in our study and the experimental protocols used were approved by Research and Ethics committee of the School of Pharmacy, Addis Ababa University.

\section{Extraction of essential oil}

About $3 \mathrm{Kg}$ of the fresh leaves of $F$. vulgare were distilled by hydrodistillation for a period of about $3 \mathrm{~h}$ using Clevenger-type apparatus. The oil was dried over anhydrous sodium sulphate to remove traces of moisture and stored in a vial inside a refrigerator at $4^{\circ} \mathrm{C}$ until use.

\section{Acute toxicity study}

Acute oral toxicity study was determined by using five female mice weighing $25-30 \mathrm{~g}$. The mice were fasted for $3 \mathrm{~h}$ prior to the experiment. The mice were administered using oral gavage a single high dose $(2000 \mathrm{mg} / \mathrm{kg})$ of the essential oil and were observed for any symptoms of toxicity continuously for $1 \mathrm{~h}$, intermittently for $4 \mathrm{~h}$, over a period of $24 \mathrm{~h}$ and for 14 days [33].

\section{Experimental designs}

The mice were randomly divided into six groups $(n=6)$. The first group received the vehicle (5\% Tween 80 in distilled water), the second group received standard drug, diazepam $(0.5 \mathrm{mg} / \mathrm{kg}$, Ip). Groups III to VI using oral gavage received 50, 100, 200 and $400 \mathrm{mg} / \mathrm{kg}$ doses of the essential oil, respectively. The doses were selected based on the results of the oral acute toxicity study. Taking into account the safety of the essential oil, $1 /$ 10th of the maximum dose $(2000 \mathrm{mg} / \mathrm{kg})$ given in the toxicity study limit test was considered as a middle dose $(200 \mathrm{mg} / \mathrm{kg})$. Double, one-fourth and half of the middle dose were assigned as high dose $(400 \mathrm{mg} / \mathrm{kg})$, first low dose $(50 \mathrm{mg} / \mathrm{kg})$ and second low dose $(100 \mathrm{mg} / \mathrm{kg})$ respectively.

After 30 min of diazepam treatment or 60 min essential oil/vehicle pretreatment, the mice were individually placed in animal models. All the tests were carried out at night with a minimal amount of background noise. After each 
test, the maze was cleaned with ethyl alcohol to eliminate any olfactory cues to the next animal [34].

\section{Elevated plus maze (EPM)}

The test was conducted using apparatus validated by Lister [35]. After each mouse was placed in the centre of the maze facing one of the open arms, the number of entries made into the open and closed arms and the time spent in them was recorded, using a video camera for the next five min. From these data, the percentage of entries and the percentage of time spent in each arms was calculated.

\section{Staircase test (SCT)}

SCT was carried out as used by Simiand et al. [36]. Each mouse was placed on the floor of the box with its back to the staircase, then the number of steps climbed and the numbers of rears were recorded over 3 min period using a video camera placed over head. A step is considered to be climbed only if the mouse had placed all four paws on the step, the number of steps descended was not taken into account.

\section{Open field test (OFT)}

The test was conducted as described by Aragao et al. [37]. Briefly, the mice were placed individually in a corner square of the OFT apparatus and the total number of squares crossed at the periphery, number of central squares crossed, total number of squares traveled, and the time the mouse spent in the center were video recorded for $5 \mathrm{~min}$.

\section{Statistical analysis}

The data are presented as mean \pm S.E.M (standard error of mean) of six mice. Statistical analysis of the data was performed using one-way analysis of variance (ANOVA) followed by Tukey posthoc test. Significant differences were set at $\mathrm{P}$ values lower than 0.05 .

\section{Results}

\section{Acute toxicity test}

After the administration of $2000 \mathrm{mg} / \mathrm{Kg}$ dose of the essential oil of $F$. vulgare, the animals didn't show loss of weight, autonomic behavioral changes or other signs of toxicity. There was also no mortality observed in the study period, suggesting that the LD50 (median lethal oral dose) of the essential oil is higher than $2000 \mathrm{mg} / \mathrm{kg}$ when given orally [33].

\section{Anxiolytic effects}

In the EPM paradigm (Table 1), the essential oil at $200 \mathrm{mg} / \mathrm{kg}$ dose showed significant increase in the number of entries into the open arms compared to the negative control, while all other doses of the oil did not significantly affect the parameter compared. On the other hand, none of the doses of the oil or diazepam significantly affected the number of closed arm entries except the $400 \mathrm{mg} / \mathrm{kg}$ dose which significantly decreased the parameter. The time the mice spent in the open arms was significantly increased in animals treated with 100 and $200 \mathrm{mg} / \mathrm{kg}$ doses of the oil compared to the control group. Mice treated with 100 and $200 \mathrm{mg} / \mathrm{kg}$ doses significantly increased the percentage of open arm entry compared to the vehicle (Figure 1) and at a dose of $200 \mathrm{mg} / \mathrm{kg}$ the oil produced a significant reduction in the percentage of time spent in the closed arms (Figure 2).

In SCT (Table 2), mice treated with the 100 and $200 \mathrm{mg} / \mathrm{kg}$ doses of the oil showed significant reduction of rearing compared to control group, however, only $200 \mathrm{mg} / \mathrm{kg}$ dose of the oil showed statistically significant reduction in rearing compared with diazepam. The reduction in the number of climbing was produced by the essential oil only at $400 \mathrm{mg} / \mathrm{kg}$ dose compared with control, while other doses were not effective.

In the OFT model, the number of central squares crossed was increased in all groups treated with the essential oil, however, statistical significance was reached only in the groups treated with $200 \mathrm{mg} / \mathrm{kg}$ compared to the control (Table 3). In mice treated with $400 \mathrm{mg} / \mathrm{kg}$ the

Table 1 The behavior of mice treated with the essential oil of Foeniculum vulgare and reference compounds in the elevated plus maze model

\begin{tabular}{|c|c|c|c|c|c|c|c|}
\hline \multirow[t]{2}{*}{ Treatment } & \multirow{2}{*}{$\begin{array}{l}\text { Dose, } \\
\mathrm{mg} / \mathrm{kg}\end{array}$} & \multicolumn{3}{|c|}{ Number of entries (counts/5 min) } & \multicolumn{3}{|c|}{ Time spent (sec/5 min) } \\
\hline & & Open arm & Closed arm & Total & Open arm & Closed arm & Center \\
\hline Vehicle & - & $3.17 \pm 1.33$ & $8.50 \pm 2.59$ & $11.67 \pm 3.66$ & $44.17 \pm 20.19$ & $137.83 \pm 38.24$ & $118.00 \pm 41.25$ \\
\hline FV & 50 & $4.83 \pm 1.72$ & $6.83 \pm 0.75$ & $11.66 \pm 1.37$ & $68.00 \pm 25.69$ & $117.50 \pm 46.78$ & $114.50 \pm 50.03$ \\
\hline FV & 100 & $7.50 \pm 4.59$ & $5.83 \pm 3.31$ & $13.66 \pm 3.78$ & $109.67 \pm 48.64^{\mathrm{a}^{*}}$ & $99.83 \pm 43.32$ & $90.50 \pm 33.59$ \\
\hline FV & 200 & $11.00 \pm 5.48^{\mathrm{a}^{*}}$ & $8.00 \pm 4.90$ & $19.00 \pm 9.87^{c^{*}}$ & $112.67 \pm 35.62^{\mathrm{a}^{*}}$ & $71.33 \pm 37.17^{\mathrm{a}^{*}}$ & $119.00 \pm 36.87$ \\
\hline FV & 400 & $4.01 \pm 2.10$ & $4.00 \pm 1.4^{\mathrm{a}^{*}}$ & $8.00 \pm 2.76^{(b, d)^{*}}$ & $87.50 \pm 36.32$ & $93.33 \pm 35.27$ & $119.17 \pm 27.13$ \\
\hline Diazepam & 0.5 & $10.83 \pm 9.06^{\mathrm{a}^{*}}$ & $6.50 \pm 2.59$ & $17.50 \pm 8.53^{c^{*}}$ & $123.67 \pm 50.67^{a^{* *}}$ & $67.33 \pm 34.63^{\mathrm{a}^{*}}$ & $84.67 \pm 44.23$ \\
\hline
\end{tabular}

Data are presented as mean \pm S.E.M, $\mathrm{n}=6$, ${ }^{*} \mathrm{P}<0.05,{ }^{*} \mathrm{P}<0.01,{ }^{\mathrm{a}}$ against control, ${ }^{\mathrm{b}}$ against $200 \mathrm{mg} / \mathrm{kg}$, against $400 \mathrm{mg} / \mathrm{kg},{ }^{\mathrm{d}}$ against diazepam; FV $=$ Foeniculum vulgare essential oil. 


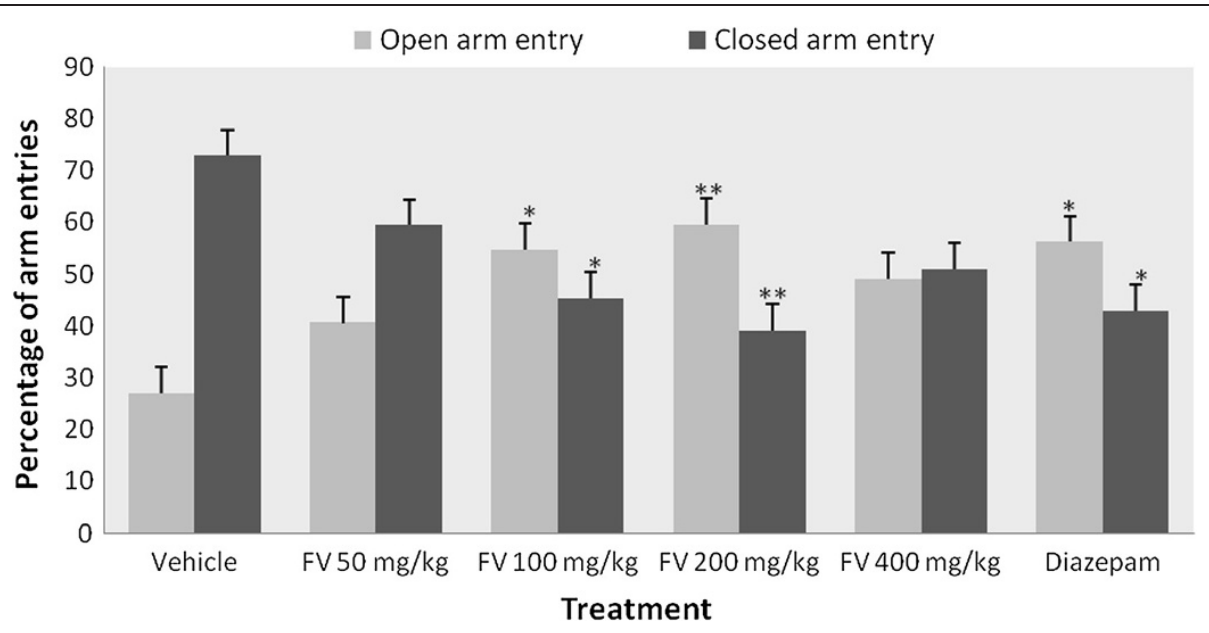

Figure 1 Effects of the essential oil of Foeniculum vulgare and controls on percentage of arm entries in the elevated plus maze (EPM) test in mice. Data are mean \pm S.E.M $(n=6) ;{ }^{*} P<0.05$, ${ }^{*} P<0.01$, compared with vehicle. FV = Foeniculum vulgare essential oil.

oil, a significant reduction in the number of squares crossed at the periphery compared to both vehicle and $200 \mathrm{mg} / \mathrm{kg}$ dose was noted. Mice treated with 100 and $200 \mathrm{mg} / \mathrm{kg}$ dose of the essential oil spent more time in the central squares compared to the control group.

\section{Discussion}

The present work has evaluated the anxiolytic activity of various doses of the essential oil of $F$. vulgare in mice employing three non-conditioned behavioral animal models of anxiety; EPM model, OFT and SCT. These tests are classic and standard models for screening central nervous system actions providing information about anxiety and psychomotor performance [38]. Further, these models can create an anxiety state in normal rodents in a reproducible paradigm while minimizing some of the confounding factors of other conditioned assays [39].

The EPM test is principally based on the behavior that exposure of animals to an elevated maze alley evokes an approach-avoidance conflict and rodents consistently spend greater time in the closed arms when placed in mazes comprising of open and closed arms [40]. Based on these assertions, EPM tests are reliable means of identifying selective anxiolytic effect of drugs and used as a tool in the investigation of the psychological and neuro-chemical basis of anxiety, for screening anxietymodulating drugs or mouse genotypes [41]. The EPM test has been validated pharmacologically, physiologically and behaviorally, and has become one of the most widely used behavioral tests for anxiety [34]. Anxiety is induced by a fear due to height in rodents when placed on the EPM. The ultimate manifestation of anxiety is exhibited by preference to remain at safer places and a decrease in the motor activity.

Treatment of mice with the essential oil of $F$. vulgare resulted in significant alterations on the behavioral responses measured in the EPM test. Experimental animals treated with 100 and $200 \mathrm{mg} / \mathrm{kg}$ doses of $F$.

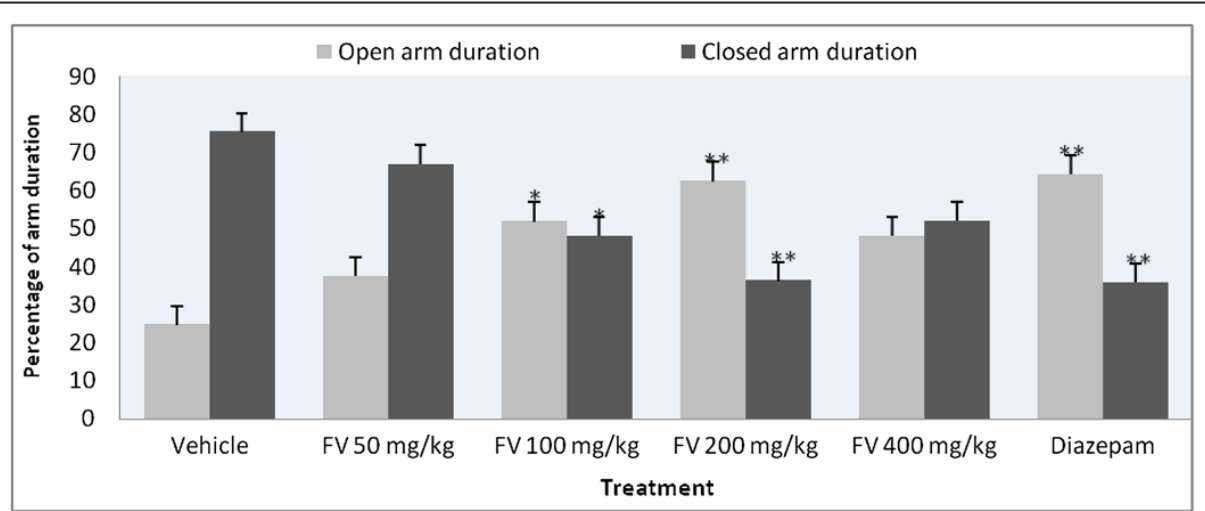

Figure 2 Effects of the essential oil of Foeniculum vulgare and controls on the percentage of duration in arms in the elevated plus maze test in mice. Data are expressed as mean \pm S.E.M. $(n=6) ;{ }^{* P}<0.05$, ${ }^{* *} \mathrm{P}<0.01$ as compared to control. FV = Foeniculum vulgare essential oil. 
Table 2 Effect produced by administration of the essential oil of Foeniculum vulgare and reference compounds to mice in the staircase test

\begin{tabular}{|c|c|c|c|}
\hline Treatment & Dose (mg/kg) & Number of rearing & $\begin{array}{l}\text { Number of } \\
\text { stairs climbed }\end{array}$ \\
\hline Vehicle & - & $19.67 \pm 2.50$ & $16.17 \pm 6.11$ \\
\hline FV & 50 & $15.00 \pm 1.67^{d^{* *}}$ & $18.00 \pm 4.19 \mathrm{e}^{\mathrm{e}^{* *}}$ \\
\hline FV & 100 & $13.33 \pm 4.93^{\mathrm{a}^{*} \mathrm{~d}^{*}}$ & $13.34 \pm 1.37$ \\
\hline FV & 200 & $8.00 \pm 3.03^{(a, b, e)^{* *} .(c, f)^{*}}$ & $11.50 \pm 3.56$ \\
\hline FV & 400 & $18.33 \pm 3.44^{\mathrm{d}^{* *}}$ & $9.50 \pm 4.09 \mathrm{a}^{* *} \cdot \mathrm{b}^{* *}$ \\
\hline Diazepam & 0.5 & $14.00 \pm 3.29^{\left(\mathrm{a}^{*} . \mathrm{d}^{*}\right)}$ & $12.00 \pm 4.56$ \\
\hline
\end{tabular}

Data are mean \pm S.E.M, $\mathrm{n}=6{ }^{\text {a }}{ }^{\mathrm{c}}$ compared with vehicle, ${ }^{\mathrm{b}}$ to $50 \mathrm{mg} / \mathrm{kg}$, ${ }^{\mathrm{c}}$ to $100 \mathrm{mg} / \mathrm{kg},{ }^{d}$ to $200 \mathrm{mg} / \mathrm{kg}$, ${ }^{\text {to }} 400 \mathrm{mg} / \mathrm{kg}$, ${ }^{f}$ to diazepam, ${ }^{*} \mathrm{P}<0.05$, ${ }^{* *} \mathrm{P}<0.01$. $\mathrm{FV}=$ Foeniculum vulgare essential oil.

vulgare essential oil showed significantly increased percentage of number of entries into the open arms. This decreased aversion to open arms compared to control group indicated its anxiolytic activity [40]. The decrease in aversion to open arms by the 100 and $200 \mathrm{mg} / \mathrm{kg}$ doses of the oil was also verified by the increased percentage of time spent in the open arms compared with the negative control.

Time spent in the central platform of EPM appears to be related to decision making and/or risk assessment. A decreased time spent on the central platform serves as indicator of a reduced decision making behavior, a parameter accepted as reliable indicators of anxiety and fearfulness [42]. However, neither doses of the essential oil nor diazepam altered the parameter significantly compared to control. At a dose of $400 \mathrm{mg} / \mathrm{kg}$, however, the oil showed a significant decrease on the number of entries in the closed arms. The absence of significant modification in the number of closed arm entries, in the anxiolytic doses of the oil, in the EPM indicated that the anxiolytic activity was observed at doses that did not impair motor activity [43].

The EPM test is one of the most popular tests for search of new benzodiazepine-like anxiolytic agents [44]. In this context, the activity of the essential oil of $F$. vulgare (100 and $200 \mathrm{mg} / \mathrm{kg}$ ) in relieving anxiety in this model may suggest a possible positive modulation of the GABA-A/benzodiazepine receptor complex.

The SCT for screening anxiolytic activity is a simple and rapid procedure for preliminary screening of anxiolytic agents [45]. Step climbing reflects exploratory or locomotor activity, while rearing behavior was a manifestation of anxiety state [46]. The present study showed that exposure of the experimental animals to the essential oil of $F$. vulgare significantly reduced rearing activity at doses (100 and $200 \mathrm{mg} / \mathrm{kg}$ ) that did not suppress climbing, aligning with a behavior of an anxiolytic compound in a staircase model [47]. At a dose of $400 \mathrm{mg} / \mathrm{kg}$, the essential oil produced a significant reduction in the number of steps ascended indicating suppression of locomotor activity, which is interpreted as a sedative, rather than anxiolytic effect in different studies $[46,48]$. Only GABA receptor complex active agents have been shown to reduce rearing at doses that do not reduce climbing in the SCT. Other non-benzodiazepine compounds induce non-specific suppression of both rearing and climbing behavior [49], strengthening the suggested possible mechanism of the oil.

The OFT is a classical animal model used to evaluate effects of drugs on anxiety, general motor activity and exploratory behavior. It uses the normal aversion of rodents to an open, brightly lit area, as the confrontation with the situation induces anxiety behavior in rodents [50]. Rodents normally spend more time in the protective corners, suggesting that the walls confer anxiety-relieving body contact. When animals are placed in OFT, they express their anxiety by a decrease in exploratory behavior [51].

Increased entry and the time spent in the center of the arena in the OFT reflects decreased anxiety altered by anxiolytic property, as measures of central exploration are often regarded as anxiety-related indices [52]. Diazepam significantly increased the total number of squares traveled at the periphery, which may be an increase in exploratory activity on reduced anxiety. The anxiolytic activity of the essential oil at the effective doses (100 and $200 \mathrm{mg} / \mathrm{kg}$ ), could not be confirmed by this parameter, as the increase

Table 3 Effect of the essential oil of Foeniculum vulgare and reference compounds on the behavior of mice in the open field model

\begin{tabular}{|c|c|c|c|c|}
\hline \multirow[t]{2}{*}{ Treatment } & \multirow{2}{*}{$\begin{array}{l}\text { Time spent in } \\
\text { central squares } \\
\text { (sec) }\end{array}$} & \multicolumn{3}{|c|}{ Number of squared crossed } \\
\hline & & Center & Periphery & Total \\
\hline Vehicle & $2.17 \pm 1.33$ & $2.00 \pm 1.26$ & $85.17 \pm 19.37$ & $87.16 \pm 19.31$ \\
\hline FV50 & $3.33 \pm 5.92 \mathrm{c}^{*}$ & $3.67 \pm 7.12^{d^{*}}$ & $80.83 \pm 25.34$ & $84.50 \pm 25.99$ \\
\hline FV100 & $10.67 \pm 4.32^{(a, b)^{*}}$ & $9.00 \pm 7.54$ & $79.33 \pm 10.32^{f * *}$ & $88.33 \pm 17.81^{f * *}$ \\
\hline FV200 & $10.50 \pm 4.04^{a^{*}}$ & $14.50 \pm 3.27^{(\mathrm{a}, \mathrm{b}, \mathrm{e})^{*}}$ & $87.50 \pm 19.67^{(\mathrm{e}, \mathrm{f})^{*}}$ & $102.00 \pm 21.87 \mathrm{e}^{*}$ \\
\hline FV400 & $4.50 \pm 5.92$ & $3.34 \pm 4.55^{\mathrm{d}^{*}}$ & $53.00 \pm 4.94^{(a, d) *}$ & $56.33 \pm 7.76^{\mathrm{d}^{*}}$ \\
\hline Diazepam & $9.33 \pm 5.32 \mathrm{a}^{\mathrm{a}^{*}}$ & $12.83 \pm 10.66^{\mathrm{a}^{*}}$ & $122.67 \pm 31.6^{(a, d)^{*} \cdot c^{* *}}$ & $133.83 \pm 34.93^{(\mathrm{a}, \mathrm{c})^{* *}}$ \\
\hline
\end{tabular}

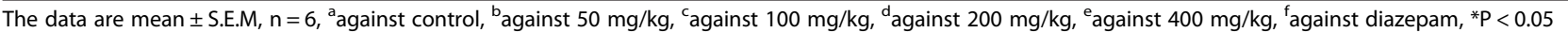
and ${ }^{* *} \mathrm{P}<0.01$. FV $=$ Foeniculum vulgare essential oil. 
in locomotor activity can be used as indice of anxiolytic effect [53]. The decrease in ambulation at the highest dose $(400 \mathrm{mg} / \mathrm{kg})$ of the oil might be due to the sedative property of the oil. Suppression of exploratory behavior is an indication of central nervous system depressant activity [44]. This decline in activity at highest doses of the essential oil in EPM, SCT and OFT can be correlated well with each other.

In the present study, the activity of $F$. vulgare corresponding to the doses given had seemingly a biphasic inverted- $U$ (bell) shape, as the administration of the highest $(400 \mathrm{mg} / \mathrm{kg})$ and lowest $(50 \mathrm{mg} / \mathrm{kg})$ doses showed insignificant low effects whereas the $100 \mathrm{mg} / \mathrm{kg}$ and $200 \mathrm{mg} / \mathrm{kg}$ dose levels produced significant effects and the peak in mean response was shown at $200 \mathrm{mg} / \mathrm{kg}$. The ineffectiveness of the lowest dose of the oil may be because it is a sub-threshold level. However, the lack of effect at the highest dose level may be due to a decreased locomotion which might be due to an interference with a normal sensory-motor function or sedative effect. The sedative activity of the essential oil is also verified by a research [54]. Such inverted U-shaped functions are also typical of conventional anxiolytics (benzodiazepines and buspirone) that, in addition to reducing anxiety, also impair motor performance at high doses [55].

The effects of $F$. vulgare essential oil in the anxiety models were comparable or better in some cases to those of the standard anxiolytic drug diazepam at the doses used. Overall, the results indicated that the essential oil of F. vulgare can be further studied for optimum dosage to be used as a future of anti-anxiety drug development or as a standardized Phytomedicine.

The major component of the essential oil, anethole, which is the methyl ether of estrone, has been reported to display a potent estrogenic activity [56]. There is a correlation between decreased estrogen levels and increased anxiety $[57,58]$. Further, anethole has a structural similarity with dopamine [59]. In other studies [60,61], the minor components of the essential oil of $F$. vulgare including $(+)$-limonene, linalool, pinene and eugenol have also been reported to have anxiety relieving like activities.

\section{Conclusion}

The lower doses of the essential oil of the aerial parts of F. vulgare possess anxiolytic activity, while at a higher dose the oil appears to be potentially sedative. Thus, the results of the present study indicate that the essential oil of $F$. vulgare may have potential clinical applications in the management of anxiety.

\footnotetext{
Abbreviations

F. vulgare: Foeniculum vulgare; EPM: Elevated plus maze; SCT: Staircase test; OFT: Open field test.
}

Competing interests

The authors declare that they have no competing interests.

\section{Authors' contributions}

MM conceived the study, designed and conducted all laboratory experiments; analyzed and interpreted experimental results. KA and WS participated in the proposal, study design and manuscript preparations. All authors read and approved the final manuscript.

\section{Acknowledgements}

The authors are grateful to Ato Melaku Wondafrash, the National Herbarium, Addis Ababa University for identification of the plant material. One of us (MM) would like to acknowledge the office of the Vice President for Research and Dean of Graduate Studies for providing financial support.

\section{Author details}

${ }^{1}$ Department of Pharmacology and clinical Pharmacy, School of Pharmacy, Addis Ababa University, Addis Ababa, Ethiopia. ${ }^{2}$ Department of Pharmaceutical Chemistry and Pharmacognosy, School of Pharmacy, Addis Ababa University, Addis Ababa, Ethiopia.

Received: 6 March 2014 Accepted: 19 August 2014

Published: 23 August 2014

\section{References}

1. Shri R: Anxiety: causes and management. J Behav Sci 2010, 5:100-118.

2. Kessler RC, Greenberg PE: The economic burden of anxiety and stress disorders. In Neuropsychopharmacology: the fifth generation of progress: American College of Neuropsychopharmacology. Edited by Kenneth LD, Dennis C, Joseph TC, Charles N. Philadelphia, Lippincott: Williams \& Wilkins; 2002.

3. Hoffman DL, Dukes EM, Wittchen HU: Human and economic burden of generalized anxiety disorder. Depress Anxiety 2008, 25(1):72-90.

4. Eysenck MW, Derakshan N: New perspectives in attentional control theory. Personal Individ Differ 2011, 509:55-960.

5. Durant C, Christmas D, Nutt D: The pharmacology of anxiety. Curr Top Behav Neurosci 2010, 2:303-330.

6. Marohn S: What is Anxiety and Who Suffers from it? The Natural Medicine Guide to Anxiety. Newburyport, Massachusetts: Hampton Roads Publishing Company; 2003.

7. Atack JR: GABAA receptor a2/a3 subtype-selective modulators as potential nonsedating anxiolytics. Curr Top Behav Neurosci 2010, 2:331-360.

8. Treit D, Engin E, McEown K: Animal models of anxiety and anxiolytic drug action. Curr Top Behav Neurosci 2010, 2:21-60.

9. Nastassja K, Dan JS: Pharmacotherapy of anxiety disorders: a critical review. Dialogues Clin Neurosci 2011, 13(4):423-437.

10. Hood S, Ayonrinde D, Davidson R, Martin-Iverson M, Samuel M, Schenk M, Sim M, Wynn Owen P, Lyon D: Anxiety Disorders Drug Treatment Guidelines. Perth, WA, Australia: Western Australian Psychotropic Drugs Committee, Western Australian Therapeutics Advisory Group; 2008.

11. Ravindran LN, Stein MB: Pharmacotherapy of post-traumatic stress disorder Curr Top Behav Neurosci 2010, 2:505-525.

12. Yorbik Ö, Birmaher B: Pharmacological treatment of anxiety disorders in children and adolescents. Bull Clin Psychopharmacol 2003, 13:133-141.

13. Gray J: Therapeutic choices. 4th edition. Ottawa, Canada: Canadian Pharmacist Association; 2003.

14. Mahe $V$, Balogh A: Long-term pharmacological treatment of generalized anxiety disorder. Int Clin Psychopharmacol 2000, 15:99-105.

15. Zhang ZJ: Therapeutic effects of herbal extracts and constituents in animal models of psychiatric disorders. Life Sci 2004, 75:1659-1699.

16. Gnatta JR, Dornellas EV, Paes da Silva MJ: The use of aromatherapy in alleviating anxiety. Acta Paulista de Enfermagem 2011, 24:257-263.

17. Aprotosoaie AC, Spac A, Hăncianu M, Miron A, Tănăsescu VF, Dorneanu V, Stanescu U: The chemical profile of essential oils obtained from fennel fruits (Foeniculum vulgare mill.). Farmacia 2010, 58:46-53.

18. He W, Huang B: A review of chemistry and bioactivities of a medicinal spice: Foeniculum vulgare. J Med Plants Res 2011, 5:595-3600.

19. Nassar MI, Aboutabl EA, Makled YA, El-Khrisy EDA, Osman AF: Secondary metabolites and pharmacology offoeniculum vulgaremill. ubsp Piperitum. Rev Latinoamer Quím 2010, 38(2):1-10. 
20. Gulfraz M, Mehmood S, Minhas N, Jabeen N, Kausar R, Jabeen K, Arshad G: Composition and antimicrobial properties of essential oil of Foeniculum vulgare. Afr J Biotechnol 2008, 7:4364-4368.

21. Food and Drug Administration: Health and human services. 1976:582 sec.409.

22. Swann P or Debby: Fennel essential oil. www.tracesetc.com, accessed online on .2008. 05/02/2011.

23. Wynn SG: Case report: chronic abdominal pain in a dog. J Am Holist Vet Med Assoc 2004, 23:33-39.

24. Ozcan MM, Sagdiç O, Ozkan G: Inhibitory effects of spice essential oils on the growth of Bacillus species. J Med Food 2006, 9:418-421.

25. Barros L, Heleno SA, Carvalho AM, Isabel CFR: Food and chemical toxicology systematic evaluation of the antioxidant potential of different parts of Foeniculum vulgare Mill. Ferreira 2009, 47:2458-2464.

26. Chainy GB, Manna SK, Chaturvedi MM, Aggarwal BB: Anethole blocks both early and late cellular responses transduced by tumor necrosis factor: effect on NF-KB, AP-1, JNK, MAPKK and apoptosis. Oncogene 2000 19:2943-2950

27. Oulmouden F, Saïle R, Gnaoui NE, Benomar H, Lkhider M: Hypolipidemic and anti- atherogenic effect of aqueous extract of fennel (Foeniculum Vulgare) extract in an experimental model of atherosclerosis induced by triton WR-1339. Eur J Sci Res 2011, 52:91-99.

28. Birdane FM, Cemek M, Birdane YO, Gulcin I, Buyukokuroglu ME: Beneficial effects of Foeniculum vulgare on ethanol/induced acute gastric mucosal injury in rats. World J Gastroenterol 2007, 13:607-607.

29. Ozbek H, Ugras S, Dülger H, Bayram I, Tuncer I, Ozturk G: Hepatoprotective effect of Foeniculum vulgareessential oil. Fitoterapia 2003, 74:317-31.

30. Wright $\mathrm{Cl}$, Van-Buren L, Kroner Cl, Koning MM: Herbal medicines as diuretics: a review of the scientific evidence. J Ethnopharmacol 2007, 114:1-3.

31. Divekar A, Oswal RJ, Bagul YR, Antre RV: The pharmacological evaluation of Foeniculum vulgare Miller for antianxiety. Imperial J Pharmacol Toxicol 2011, 1:16-20.

32. Kishore RN, Anjaneyulu N, Ganesh MN, Sravya N: Evaluation of anxiolytic activity of ethanolic extract of Foeniculum vulgare in mice model. Int J Pharm Pharm Sci 2012, 4:584-586.

33. Organization for Economic Cooperation and Development: OECD Guidelines for the Testing of Chemicals. Acute Oral Toxicity -Up-And-Down-Procedure. UDP; 425. France: OECD Publishing; 2008.

34. Garg DV, Dhar VJ, Sharma A, Dutt R: Experimental model for antianxiety activity: a review. Pharmacologyonline 2011, 1:394-404.

35. Lister RG: The use of a plus-maze to measure anxiety in the mouse. Psychopharmacology 1987, 92:180-185.

36. Simiand J, Kean PE, Morre M: The staircase test in mice: a simple and efficient procedure for primary screening of anxiolytic agents. Psychopharmacology 1984, 84:48-53.

37. Aragao GF, Carneiro LMV, Junior APF, Vieira LC, Bandeira PN, Lemos TLG, Viana GS: A possible mechanism for anxiolytic and antidepressant effects of alpha-and beta-amyrin fromProtium heptaphyllum(Aubl.). Pharmacol Biochem Behav 2006, 85:827-834.

38. Sousaa FCF, Meloa CTV, Monteiroa AP, Limaa VTM, Gutierrezb SJC, Pereiraa BA, Barbosa-Filho JM, Vasconcelos SM, Fonteles MF, Viana GS: Antianxiety and antidepressant effects of riparin III fromAniba riparia (Nees) Mez (Lauraceae) in mice. Pharmacol Biochem Behav 2004, 78:27-33.

39. Eguchia J, Inomatab Y, Saitoa K: The anxiolytic-like effect of $\mathrm{MCl}-225$, a selective NA reuptake inhibitor with 5-HT3 receptor antagonism. Pharmacol Biochem Behav 2001, 68:677-683.

40. Saivasanthi V, Gowthamigoud SK, Aakruthi SR, Gupta A, Rao AS: Evaluation of Caralluma fimbrita for analgesic, anti inflammatory and anxiolytic activities. Int J Pharm 2011, 1:40-45.

41. Bourin M, Petit-Demouliére B, Dhonnchadha BN, Hascoet M: Animal models of anxiety in mice. Fundam Clin Pharmacol 2007, 21:567-574

42. Gagan S, Richa S, Avninder M, Sandeep R, Vivek P: Anxiolytic effects of Elaeocarpus sphaericus fruits on the elevated plus-maze model of anxiety in mice. Int J PharmTech Res 2010, 2:1781-1786.

43. Griebel G, Simiand J, Gal CS, Wagnon J, Pascal M, Scatton B, Maffrand J, Soubrié P: Anxiolytic- and antidepressant-like effects of the non-peptide vasopressin V1b receptor antagonist, SSR149415, suggest an innovative approach for the treatment of stress-related disorders. Proc Natl Acad Sc 2002, 99:6370-6375.
44. Akindele AJ, Adeyemi OO: Anxiolytic and sedative effects of Byrsocarpus coccineus Schum. and Thonn. (Connaraceae) extract. Int J Appl Res Nat Products 2010, 3:28-36

45. Emmanouil DE, Quock RM: Effects of benzodiazepine agonist, inverse agonist and antagonist drugs in the mouse staircase test. Psychopharmacology 1990, 102:95-97.

46. Milman A, Weizman R, Rigai T, Rice KC, Pick CG: Behavioral effects of opioid subtypes compared with benzodiazepines in the staircase paradigm. Behav Brain Res 2006, 170:141-147.

47. Õkva K, Lang A, Nevalainen T, Maurane K, Väli M, Pokk P: Effects of litter origin and weight on behaviour of outbred $\mathrm{NIH} / \mathrm{S}$ mice in plus-maze and staircase tests. Scand J Lab Anim Sci 2008, 35:127-134.

48. Bellavite $\mathrm{P}$, Magnani P, Marzotto M, Conforti A: Assays of homeopathic remedies in rodent behavioural and psychopathological models. Homeopathy 2009, 98:208-227.

49. Weizmann R, Pazc L, Peter Y, Toren P, Pick CG: Behavioral effects of agents active at the $\gamma$-aminobutyric acid receptor complex in the staircase paradigm. Brain Res 2001, 901:137-142.

50. Hossain M, Raquibul HSM, Mukta M, Akter R, Mazumder EH: Anxiogenic activity of methanol extracts of Artocarpus Lacucha Buch.-Ham. fruit parts and leaf in mice. Eur J Sci Res 2010, 46:592-603.

51. Hliňak Z, Hynie S, Krejči I, Klenerova V: Novel and simple behavioral paradigm for assessing anxiety in rats: effect of diazepam. Neuroendocrinol Lett 2009, 30:25-31.

52. Ramos A: Animal models of anxiety: do I need multiple tests? Trends Pharmacol Sci 2008, 10:493-498.

53. Prut $L$, Belzung $C$ : The open field as a paradigm to measure the effects of drugs on anxiety-like behaviors: a review. Eur J Pharmacol 2003, 463:3-33.

54. Shipochliev T: Pharmacological research into a group of essential oils - effect on the motor activity and general state of white mice in separate applications or after iproniazid phosphate. Veterinarno-Meditsinski Nauki 1968, 5:87-92.

55. Jenck F, Moreau JL, Martin JR, Kilpatrick GJ, Reinscheid RK, Monsma FJ Jr, Nothacker HP, Civelli O: Orphanin FQ acts as an anxiolytic to attenuate behavioral responses to stress. Neurobiology 1997, 94:14854-14858.

56. Dhar SK: Anti-fertility activity and hormonal profile of trans-anethole in rats. Indian J Physiol Pharmacol 1995, 39:63-67.

57. Osterlund MK, Witt MR, Gustafsson JA: Estrogen action in mood and neurodegenerative disorders: estrogenic compounds with selective properties-the next generation of therapeutics. Endocrine 2005, 28:235-242.

58. Donner N, Handa RJ: Estrogen receptor beta regulates the expression of tryptophan-hydroxylase-2 mRNA within serotonergic neurons of the rat dorsal raphe nuclei. Neuroscience 2009, 163:705-718.

59. Alexandrovich I, Rakovitskaya O, Kolmo E, Sidorova T, Shushunov S: The effect of fennel (Foeniculum vulgare) seed oil emulsion in infantile colic: a randomized, placebo-controlled study. Altern Ther 2003, 9:58-61.

60. Aoshima $\mathrm{H}$, Hamamoto $\mathrm{K}$ : Potentiation of GABAA receptors expressed in Xenopus oocytes by perfume and phytoncid. Biosci Biotechnol Biochem 1999, 63:743-748.

61. Lima NG, De Sousa DP, Pimenta FC, Alves MF, De Souza FS, Macedo RO, Cardoso RB, de Morais LC, Melo Diniz Mde F, de Almeida RN: Anxiolytic-like activity and GC-MS analysis of (R)-(+)-limonene fragrance, a natural compound found in foods and plants. Pharmacol Biochem Behav 2012, 3:450-454.

doi:10.1186/1472-6882-14-310

Cite this article as: Mesfin et al:: Evaluation of anxiolytic activity of the essential oil of the aerial part of Foeniculum vulgare Miller in mice. BMC Complementary and Alternative Medicine 2014 14:310. 